\title{
upf.
}

Universitat

Pompeu Fabra

Barcelona

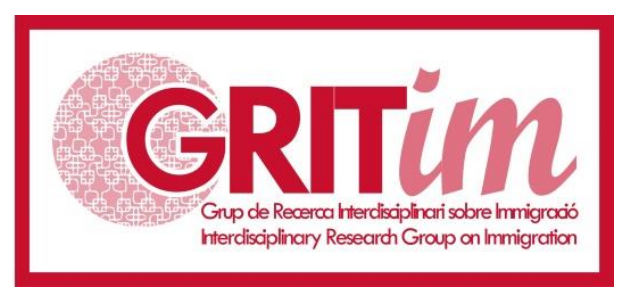

Working Paper Series

Number 41, Autumn 2019

\section{Assembling Borders, Territory and Human Rights in Migration Management Policies}

\author{
Martino Reviglio
} martino.revigliodellaveneria@unito.it

Grup de Recerca Interdisciplinari en Immigració - UPF Departament de Ciències Polítiques i Socials Universitat Pompeu Fabra www.upf.edu/web/gritim gritim@upf.edu 


\section{Abstract}

The EU is facing a migration management dilemma. The compromise between inclusion and exclusion developed by the European Court of Human Rights failed to guarantee human rights obligations and security challenges. This situation has put pressure on the member states overlooking the Mediterranean Sea namely Italy, Greece and Spain. In this scenario, these member states have attempted to pursue strategies to contain the phenomenon assuring both human rights and security. The paper analyses two different strategies developed by the Italian government in the last five years to respond to the Libyan migration crisis. These policies are the Mare Nostrum policies and the Minniti policies. These policies are designed around three components: Borders; Territory; Human Rights. The paper suggests that these pillars are assembled differently at different times to achieve specific policy goals. In doing so, the normative assemblage could be instrumental to either an inclusive or an exclusive policy.

\section{Keywords}

Migration Policies, European Court of Human Rights, Italy, Libya, Human Rights

\section{Author's biographical note}

Martino Reviglio holds a B.A. in European Studies (Maastricht University), a M.A. in History (Utrecht University) and M.Sc. in Comparative Law, Economics and Finance (International University College of Turin). Currently, he is a second year Ph.D. candidate in International Migration Law at the University of Turin, Italy. Moreover, Martino has worked as an intern at the European Parliament, and as a consultant at the Department of European Affairs of the Council of Ministers of Italy. His research focuses on migration management policies in the Central Southern Mediterranean Sea. His first publication 'Externalizing Migration Management through Soft Law: The Case of the Memorandum of Understanding between Libya and Italy' is forthcoming in Global Jurist.

Suggested citation:

Reviglio, M. (2019) “Assembling Borders, Territory and Human Rights in Migration Management Policies." GRITIM-UPF Working Paper Series, no. 41 (Autumn): http://hdl.handle.net/10230/42283

This work is licensed under the Creative Commons AttributionNonCommercial 4.0 International License. Click here to view a copy of this license. 


\section{Introduction}

The migration management policies developed by the European Union (EU) and by the member states overlooking the Mediterranean Sea from a legal perspective have been often designed on the cases decided by human rights courts and quasi-judicial bodies that decide between two competing traditions of political philosophy. The first is a universal/inclusive framework that considers human rights as integral to the individual independently of the compliance with formal conditions set by migration management policies. The second tradition is a statist/exclusive one that sees the state as the sole authority able to give access to its territory and to set the legal conditions to access to human rights protection (Thomas, 2013; Paz, 2016).

The transformation of the Central Southern Mediterranean in a space of both inclusion and exclusion is the representation of the jurisprudence developed by the European Court of Human Rights (Paz, 2016). In fact, the Court adopted the territorialitybased compromise between inclusion and exclusion. In doing so, it has reinforced the idea that human rights protection is dependent on the physical presence of the migrant on the territory. On the one hand, the Court has articulated an inclusive and universal principle of human rights protection. On the other hand, it has produced a new concept of territoriality by adopting the territoriality-based compromise as furthered exclusion (Ibid.).

To understand what the theoretical premises are before the practical ones that shaped the Central Southern Mediterranean as a space of both inclusion and exclusion, it is essential to identify the theoretical components from a legal philosophical perspective. The paper suggests that in the development of this compromise there has been an instrumental assemblage ${ }^{1}$ of three components or concepts: (I) Borders; (II) Territory; (III) Human Rights. Each of these components has a diverse interpretation in legal and social theory that can be instrumental for various purposes as in the case of migration management.

To see how these have been conceptualized, the paper analyses two migration management policies that have been pursued by Italy and by the European Union (EU) in the Central Southern Mediterranean from 2013 until 2018. The consequences of these

\footnotetext{
${ }^{1}$ Here I use the term assemblage in its most descriptive sense. See, Sassen, S. (2008) Territory, authority, rights: From medieval to global assemblages. Princeton: Princeton University Press; p. 5.
} 
policies have been several, yet the main implication has been the transformation of the Central Southern Mediterranean into a space of both inclusion and exclusion (Cuttitta, 2018a). The policies examined in the paper are the following: (I) the Mare Nostrum policies (10/2013-10/2014); (II) the Minniti policies (2/2017-2018). The aim of the paper is to show that these migration management policies have been designed around the assemblage of borders, territory and human rights. Nonetheless, in evaluating these policies, the paper offers a broader temporal perspective that considers the period within and after the implementation of the Mare Nostrum and Minniti policies.

The rest of the paper is organized as follows: Section 1 introduces the idea of assembling migration management policies and presents the three components in their specificity and performativity. In doing so, it sets out the theoretical framework that composes the assemblage in inclusive or exclusive migration management policies. Section 2 discusses the Mare Nostrum policies as an example of inclusive migration management policy. Moreover, Section 3 presents the Minniti policies as an example of exclusive management policy. Finally, Section 4 concludes by offering a critical evaluation of the two migration management assemblages. In doing so, the paper aims to shed light on the power and flexibility of components such as borders, territory and human rights in transforming the Central Southern Mediterranean into a space of both inclusion and exclusion.

\section{Assembling Migration Management}

In the past years, the EU faced a migration management dilemma (Geiger \& Pécoud, 2010). The policies developed so far by its member states oscillate between an inclusive and an exclusive migration management approach. These opposing approaches are based on different normative outlooks that recognise a universal understanding of human rights and a statist one that recognises the state as the ultimate authority to initiate human rights protection.

The inclusive or universal approach considers migrants as subjects to which human rights apply before their entrance in the territory. Thus, human rights are inherent to the individual, whether or not the individual complied with formal conditions for immigration. In doing so, the rights are initiated by the simple presence or physicality and by the proximity of the migrant to the territory of the state (Paz, 2016). In this case, the 
state has the obligation to rescue and protect migrants that reach the proximity of the Maritime Rescue Region of competence. ${ }^{2}$ Yet, in the case of Mare Nostrum, Italy has saved people at rest outside its Maritime Rescue Region (Aalberts \& Gammeltoft-Hansen, 2014).

This approach brings to its conclusion the Jamaa v. Italy ruling which recognises that the state has the obligation to rescue and protect the migrant during an interdiction in the high seas. ${ }^{3}$ In fact, this idea of jurisdiction grounded in proximity means that getting close to the border of the state would be equal to establishing territorial presence inside the state (Moreno-Lax, 2012). Thus, to go back to the landmark ruling of Jamaa v. Italy it follows that in the high seas individuals are always protected even in 'the maritime environment' there is no 'area outside the law'. ${ }^{4}$ Brought to its extreme, this approach calls for open borders by a universal application of human rights independently from territorial limitations.

The exclusive or statist approach initiates protection of migrants if they comply with the formal conditions set out by the state which require the individual to be present in the territory of the state. In doing so, it reinforces the idea of territoriality because 'the state has the sole authority to decide who may enter its domain, under what conditions and with what legal consequence' (Paz, 2016). In this second approach, the state has absolute dominion of the border and can permit the entrance only to those individuals who comply with the formal conditions of its migration management regime. Thus, merely getting in the proximity of the border does not by itself represent a condition to activate protection by the state. Moreover, jurisdiction initiates only upon entering the territory, thus proximity does not entail any legal obligation for the state. The state utilizes defined physical boundaries to stop migrants from getting in, either by land or by sea, so that their entry does not activate the state's obligations to protect them as in the case of the Minniti policies discussed further in the paper.

The paper now considers the three components assembled in migration management policies in more detail keeping in mind that: these are interdependent but

\footnotetext{
${ }^{2}$ Please do note that here the concept is not the one of border but of Maritime Rescue Region. See UNCLOS, Art. 98 (2).

${ }^{3}$ Jamaa v. Italy, 2012-II Eur. Ct. H.R. 97, II 178.

${ }^{4}$ Ibid.
} 
maintain a level of specificity and have variable levels of performance in migration management assemblages.

\section{$1.1 \quad$ Borders}

We live in a time in which borders in certain contexts disintegrate due to the forces of neoliberal globalization (de Sousa Santos, 2002). Yet in other contexts, in particular in relation to human mobility, new borders emerge as obstacles to human circulation and movement (Leon \& Overbeek, 2015). In this scenario, we observe a continuous process of border reconfiguration along lines of political and military power (Cuttitta, 2007). It seems that the objective of these policies followed on a global level is to liberate the circulation of money and financial capital by opening up financial and real markets around the world (Mezzadra \& Nelson, 2013). However, if in the last forty years we made incredible steps in abolishing the national borders that impeded the movement of capital, we nevertheless made no progress in relation to the free circulation of human beings. In fact, we are going towards the development of an idea of 'fortresses' not only in Europe but also around the world. Thus, the process of border reconfiguration represents a strategy which aims at designing two types of border: an open border for capital and a closed border for human beings. Yet, as the paper shows, there are no borders for human beings on the move, rather only ways to circumvent or to contest the border that in concrete represents a mere space of political demarcation (De Genova et al., 2015).

When we study borders, we should view them as spaces not just as lines of division (Zanini, 1997). In fact, it is in this space that different discourses produce the border in processes of 'constant encounter, tension, conflict and contestation' (De Genova et al., 2015). In doing so, borders emerge as a space in which a multitude of actors participate in the process of border configuration. Among the actors that participate in border configuration an important role is played by migrants that impact and shape the spaces of borders. Moreover, it is necessary to understand that border configuration does not represent a simple and linear binary logic of structure/agency, but rather a representation of a more complex environment in which a crucial and active role is played by migration (Ibid.). Hence, it is important to realize that the border is the creation of two antagonist forces with different power balances that struggle either to open or to close the border. 
According to Balibar, trying to define what a border is runs the risk of 'going around in circles, as the very representation of the border is the precondition for any definition' (Balibar, 2012). In fact, Balibar continues suggesting that borders possess an 'equivocal character' (Ibid.). As suggested by Novak, 'Any definition of borders is in itself a representation of the social; any representation of the social rests on a conceptualisation of borders' (Novak, 2017). It can be suggested that borders represent the result of the competition of different social, economic and military forces to design a space that is dynamic, fluid and can be used as a resource for political reasons (Sohn, 2014).

Over the last 20 years, the EU has designed a complex multilateral border regime (Hampshire, 2016; Campesi, 2018) which aimed at creating a 'securitized' and 'humanitarian' European borders (Pallister-Wilkins, 2016; Cuttitta, 2018a; Moreno-Lax, 2018). On the one hand, the EU has developed a legal and quasi-legal framework that encompasses directives, regulations, and bilateral and multilateral agreements with third countries (Adepoju et al., 2010). On the other hand, the policy framework was based on the concept of 'integrated border management' (IBM) that aims at redefining the 'political geography of border control' by the participation of different national and supranational actors and agencies (Campesi, 2018).

The significance of the EU approach became evident in light of the so-called 'migration crisis' during which it appeared evident to the EU the need to reinforce external border controls (Jeandesboz \& Pallister-Wilkins, 2016; Campesi, 2018). To do so, the EU during the Valletta summit (2015) formalised at a political level this kind of migration management policy. ${ }^{5}$ Nonetheless, the main aim of the EU was to boost the policies with third countries by designing bilateral or multilateral agreements, often in the form of soft law, to reinforce European border management. Examples of the externalizing migration management policies instigated by the EU include: the TurkeyEU statement (2016); the Libya-Italy memorandum (2017); and the Morocco-Spain agreement (2019) (Moreno-Lax \& Lemberg-Petersen, 2019).

\footnotetext{
${ }^{5}$ For detailed infomation on the Valletta Summit see the Action Plan. Available from: https://www.consilium.europa.eu/media/21839/action_plan_en.pdf [last visited: 28 August 2019]
} 
What the EU has developed is a complex system of national and international actors motivated by the ultimate objective to reinforce the control of European borders in order to diminish the arrival of migrants and the death at sea (Steinhilper \& Gruijters, 2018). To reinforce the border, the EU is 'stretching the border' of Europe until North Africa and Turkey (Cases et al., 2010; Novak, 2017). Moreover, the EU designed a system that does not give access to most migrants to what Spijkerboer calls 'global mobility infrastructure' (Spijkerboer, 2018). Indeed, the complexity of the migration management system created by the EU transforms the border of extra-EU neighbouring countries in spaces in which the EU and its member states exercise state agency on both the neighbouring state and on migrants blocked in these countries (Agnew, 2008). Thus, the border is transformed into a space, determined 'from distance' by EU governance structures, in which legal obligations and international responsibilities are blurred.

In this border configuration, borders are not only instruments to obstruct global migration flows but are rather emerging as instruments to articulate global migration flows (De Genova, 2013). Meanwhile, by becoming articulators of migration flows, borders underwent significant transformations. First, we witness a proliferation of borders in number and size. Second, borders are becoming more heterogeneous, and thus diverse (Mezzadra \& Neilson, 2013). In fact, in designing these migration management policies, these actors attribute to the border a performative function (Agnew, 2008): the border can include or can exclude (Mezzadra \& Neilson, 2013). Indeed, the capacity to either include or exclude should be regarded as a significantly flexible instrument.

Borders are becoming articulation of mobility and the ultimate aim of the actors involved in bordering is to monitor, differentiate and manage migration flows to respond to the political insecurity attached to such mobility (Bigo, 2002; Zapata-Barrero \& Gabrielli, 2017). Moreover, in these processes of bordering it is possible to recognize other two significant transformation: a process of 'delocalization of the border' (Walters, 2006) and of 'disaggregation of border functions' (Bigo, 2002). These processes are part of a wider transformation particularly evident in the European contest of 'control from distance' (Bialasiewicz, 2012). Hence, the actors involved in migration management aim at moving the control activities to third countries through a series of legal and quasi-legal instruments that are part of externalization policies (Moreno-Lax \& Lemberg-Petersen, 2019). By pursuing an externalization policy, states put in place instruments to construct 
a securitized border through 'securitizing practices' (Campesi, 2014) or 'border induced displacement' (Moreno-Lax \& Lemberg-Petersen, 2019).

An alternative elaboration to the concept of securitized border was suggested by Walters: the humanitarian border. The humanitarian border represents a specific conceptualization of the border that emerges only in specific settings and should not be intended as universal but as a multifaceted and 'overdetermined phenomenon' (Walters, 2011). It is suggested in the paper that the Mare Nostrum policies represent an instance in which the humanitarian border materializes. Indeed, the humanitarian border represents a governmental strategy that aims at constructing a humanitarian narrative at the border (Cuttitta, 2018a). Another characteristic of the humanitarian border is its instability and mobility because is a dynamic concept that changes in relation to changes in migration flows (Walters, 2011). Thus, actors involved in the design of a humanitarian border such as states, international organization and non-governmental organizations (NGOs) (Hardt $\&$ Negri, 2001) participate in the creation of migration management policies that can develop a humanitarian border (Cuttitta, 2018a).

The materialization of borders on the European frontiers has been intense in the last years (Mezzadra \& Neilson, 2013) and has gave raise to both inclusion and exclusion border management policies. On the one hand, in the inclusive policy the border is considered not as a limit to the entrance of the migrant but as a point that if it is reached activates the protection of the host state. On the other hand, for the exclusive policy the border permits the entrance only to those individuals that comply with the formal conditions set out by the state. Hence, borders can assume specific normative structures that can contribute to theorize the border as an articulator of both inclusive and exclusive migration management policies.

\subsection{Territory}

Territory is an indefinite term or concept that typically signifies 'a section of space occupied by individuals, social groups or institutions' (Agnew et al., 2008). Other elements that emerge in the process of space occupation according to Paasi are 'material elements such as land, functional elements such as the control of space, and symbolic dimensions like social identity' (Paasi, 2003). Indeed, these elements do represent what territory has always been for political geographers: the simultaneous expression of the connections between space, power and knowledge (Agnew, 1994; Paasi, 2003). As 
suggested by Knight 'territory is not; it becomes, for territory itself is passive and it is human beliefs and actions that give territory a meaning' (Knight, 1982). These processes of territory formations are part of what Paasi calls 'the institutionalization of territories' meaning 'the process during which territorial units emerge as part of the socio-spatial system and become established and identified in social action and social consciousness' (Paasi, 2003).

The concept of territory has been under investigated due to its volatile nature (Elden, 2013; Moore et al., 2014). Gottman presents one of the first investigations in the concept of territory and its relationship with state authority; he argues that, 'The concept of territory, with its material and psychological components, is a psychosomatic expedient necessary to preserve freedom and the variety of separated communities in an interdependent and accessible space' (Gottman, 1975). The two components of territory are identified as material and psychological forces that emerge at the individual level. Indeed, the construction and in particular the control of a territory needs a constant process of exchange as Sack puts it 'they are the results of strategies to affect, influence, and control people, phenomena, and relationship' (Sack, 1986).

The dynamics that shape territory in geographical and political dimensions should not be understood as ahistorical because in doing so there is a risk of missing its complexities (Elden, 2013). Moreover, as argued by Foucault 'territory is no doubt a geographical notion, but it's first of all a juridico-political one: the area controlled by a certain kind of power' (Foucault, 2007). In fact, the only institutional actor with the power to design territory as a juridico-political category is the nation state. Yet it is crucial to recognize the complexity of territory as a concept otherwise as Sassen points out, 'In much scholarly writing, territory as largely ceased to work analytically because it has been reduced to a singular meaning - nation state territory' (Sassen, 2013). Thus, to overcome what Agnew called the 'territorial trap' (Agnew, 1994), it is necessary to go beyond the linear correlation between nation state and territory in order to shed light on the multitude of actors and forces that do shape territory as a dynamic and performative concept.

Therefore, the concept of territory assumes different and at times contrasting characteristics. In this scenario, it appears evident that in the last decades we moved beyond the Westphalia system based on state territoriality (Banai et al., 2014). In this movement away from such a system, the idea of 'the end of territories' became popular 
(Badie, 1996). Nonetheless, what we are witnessing is not exactly an 'end of territories' but a constant process of territorial reconfiguration along lines of economic and political space that are able to shape the construction of territoriality (Brenner \& Elden, 2009). In fact, the construction of territoriality from a legal perspective is still conceptualized at a national level that successively is projected at an international level. Thus, nation states, despite being supported by other multilateral institutions, maintain the legal capacity to project an idea of territory and successively to construct territoriality.

Instances of these dynamics can be recognized in the 'territoriality law-making' of different nation states. For instance, the USA uses mostly private law and avoids international law while Germany constructs territoriality mostly by public law and international law making (Buxbaum, 2009). Other instances of migration management show the use of executive soft law instruments to securitize border control as in the LibyaItaly (2017) memorandum. Further, also at EU level territoriality is designed with soft law instruments as in the EU-Turkey (2016) statement. Following Sassen, these instances show that territoriality as a legal construct is not a direct relation with territory because it can go beyond territory itself. In so doing, the meaning of territory transcends its significance by encapsulating the capacity to design 'territorial informal jurisdiction' (Sassen, 2013).

To move beyond these constructions of jurisdiction, it is important to explore law 'as a territorial and territorializing device' (Brighenti, 2010). In this scenario, the law can assume both a territorializing and de-territorializing effect depending on the state's political and economic objectives. Indeed, as the paper showed above, the legal instruments to construct or deconstruct territory are numerous and differ in relation to the legal culture. Nevertheless, it is suggested here that instances of these reconfiguration of territory along economic and political spaces are clearly visible in migration management policies. At a general level, these strategies assume a different conceptualization of territory in order to design an exclusive or inclusive policy based on the decision of the European courts.

Nowadays migration management policies around the world have as a main objective the decrease of migrants' arrivals. Indeed, governments are influenced by the rise of anti-migrants' sentiments in right political parties and civic society. In Europe, for instance, the statistics collected by Eurobarometer show an increase of negative 
sentiments towards migrants in many member states. ${ }^{6}$ In order to secure the electoral support, governments of both centre-right and centre-left have attempted to design policies that were able to maintain security within their territories. The outcome of these policies was the emergence of a system of migration management conceptualized around the concept of territory.

This conceptualization is based on the compromise developed by the courts and quasi-judicial institutions that transformed the human rights application ${ }^{7}$ to what Paz calls 'access'. Paz suggests defining access as 'the ability for an individual to establish a territorial presence in the state (strong territoriality) or to come within the effective control of the state or its agents (neo-territoriality)' (Paz, 2017). Therefore, affluent states were able to design a system of migration management that is considerably associated with the concept of territory and in fact its conceptualization can achieve an inclusive or exclusive management policy (Cuttitta, 2018a). Let me briefly examine the characteristics of these two distinct but at times complementary migration management practices.

While designing an inclusive migration management policy, states have to conceptualize territory in relation to access, jurisdiction, and proximity in the following ways. First, human rights protection is not dependent on the migrants' ${ }^{\prime}$ access to territory, rather on their simple proximity to the territory. In doing so, states reinforce the concept developed by the ECtHR in the case of Jamaa vs. Italy that maintains that human rights jurisdiction is 'essentially territorial ${ }^{8}$ and is aligned with physicality and proximity (Paz, 2016). Second, states' human rights protection applies extraterritorially, meaning independently from migrants' access to these states' territories. Thus, the state assumes an extended view of human rights that if brought to the extreme can become an open borders policy that sees no territorial limitation to human rights protection (Ibid.).

By contrast, designing an exclusive migration management policy brought to the extreme can become a closed borders policy. To do so, it is first necessary to recognize human rights jurisdiction as associated to access to territory because migrants have to enter the territory and to be under the direct control of the state (Paz, 2017). Hence, in

${ }^{6}$ Special Eurobarometer presented by the European Commission (2018) 'Integration of Migrants in the European Union',. Available from: file:///C:/Users/marrevig/Downloads/ebs 469 en.pdf [last visited: 1 May 2019]

${ }^{7}$ For a detailed account of the case law that prefigured such a compromise see: Paz, M. (2016). Between the Kingdom and the Desert Sun: Human Rights, Immigration; Border Walls. Berkeley J. Int'l L., 34, 1; Paz, M. (2017). The Law of Walls. European Journal of International Law, 28(2), 601-624.

${ }^{8}$ Jamaa v. Italy, 2012-II Eur. Ct. H.R. 97, II 71. 
this approach jurisdiction is rooted in strong territoriality, meaning that human rights obligations are strictly territorial (Paz, 2016). Second, state jurisdiction and thus state responsibilities will manifest themselves only if there is a direct access to the territory of the destination state. Yet this means that migrants have to get close enough to the border to be considered for state protection. In conceptualizing territory as a strong normative category some states pursue policies that make it more difficult for migrants to reach the territory of the state.

\subsection{Human Rights}

The human rights movements in the last decades have provided the globe with 'emancipatory vocabulary and institutional machineries for people across the globe' able to design an international legal system which promotes a specific idea of justice (Kennedy, 2002). In other words, as Macklem suggests, 'Human rights are the vocabulary of justice for our globalized world' (Macklem, 2015). Nonetheless, these elaborations of human rights as promoters of justice worldwide cannot be regarded solely as a positive and dynamic force. In fact, while human rights in theory were instruments to promote justice, they also possess some critical features that make them problematic to accept tout court. First, human rights have not always complied with the aspiration of justice in part for the dominance of a moral understanding of human rights (Macklem, 2015). Second, to design a system in which the search of justice is the primary objective, it is necessary to conceptualize human rights as international legal entitlement able in theory to mitigate injustice across the world (Ibid.).

From a strictly legal point of view, human rights are international law norms. It appears from Macklem's argument that human rights have a relation with the international legal order in at least three ways. First, human rights monitor the structural dynamics of the international legal order (Lorca, 2017). Second, they mitigate the negative consequences from the way in which the international legal order is designed (Ibid.). And third, the human rights framework, by controlling and mitigating, confers legitimacy to the international order. Indeed, these argumentations unfold in the language of human rights (Ibid.). However, in order to shed light on the construction of human rights as an agenda able to promote justice across the world, it is crucial to identify what the ideological premises of such an enterprise are. 
Many scholars seem to agree that the human rights project was developed from the 1970s. Yet some like Klein suggest that the human rights movement developed in relation with the neoliberal project, and thus to understand human rights ideology we should concentrate on its relationship with the history of capitalism (Klein, 2007; O'Connell, 2007). Others like Moyn do accept the preposition that human rights emerged in the 1970s; however, they do not recognize the direct causal relation between the human rights project and neoliberalism (Moyn, 2012, 2014). In fact, Moyn argues that human rights and neoliberalism were developed in the same years and share some characteristics. Nonetheless, they still remain two parallel but separate projects (Moyn, 2014). Thus, indeed there is a critical relationship between neoliberalism and the human rights enterprise. Nevertheless, it is rather difficult to argue about a direct causal relation.

Another important element of the human rights project as pointed out by Marks is the idea developed by some scholars such as Raz (2010) and Moyn (2012) of the 'myth of presumptive universality' of human rights (Marks, 2013). While the universality of human rights can be challenged, it is important to consider the difficulties posed by the human rights application. According to Raz, the human rights project faces two problems: first, only limited practices exist to monitor and enforce the international protection of human rights; second, some claims of human rights are culturally biased and imposed by the West across the world (Raz, 2010).

Hence, for some the human rights movement can be regarded as a-political and aideological language aimed at enhancing global justice. Nonetheless, for others, what lies behind such an understanding of the human rights project is what Perugini and Gordon suggest being the role of human rights in 'the ethical, legal and practical construction of practices of domination around the world' (Perugini \& Gordon, 2015). Perugini and Gordon's book The Human Right to Dominate offers some interesting and critical reflections that merit some attention. First, human rights and violence are not antithetical but coexist in the unfolding of human rights enterprises (Ibid.). Second, they present historical instances that show the relation between human rights and domination. Third, they identify human rights as a language that frames events on legal and moral grounds in order to secure political legitimacy (Ibid). Thus, according to the authors, human rights 'constitute a highly flexible political discourse with the capacity to be constantly appropriated, translated, performed, and retooled in different political arenas' (Ibid). In so doing, it is important to recognize the flexibility and performativity of human rights 
discourses and to do a further effort to detect the invisible relations between governments, international organizations and NGOs in pursuing global justice or domination.

In this light, it is difficult to agree with one of the two positions, but a useful exercise can be to present some features of the human rights language that are common to both streams. First, the power of human rights lies in the capacity to articulate moral or ethical convictions in legal international terms and successively to support them by naming and shaming (Murdie \& Davies, 2012). Many actors participate in this complex exercise: governments, diplomacies, international organizations, NGOs, among others. Second, these articulations are presented to the public opinion as neutral and a-political. In doing so, a 'joint project' is enabled between different actors to engage in the effort of bringing global justice or domination around the world. Third, human rights tend to be presented as universal legal entitlement in order to reinforce their moral and political legitimacy. Fourth, a crucial role in promoting human rights narratives is played by activists (Klein, 2007).

Human rights narratives cannot avoid the ontological construction developed from the end of the Cold War (Baxi, 2007; Falk, 2008). On the one hand, a modern understanding of human rights that considers human rights an instrument of exclusion. On the other hand, a contemporary understanding of human rights that contemplates human rights as an instrument of inclusion (Baxi, 2007). The paper suggests that this dichotomy is displayed in international migration management policies. In fact, while states pursue an exclusive migration management policy, they assume a modern understanding of human rights namely one that excludes migrants. By contrast, states pursuing migration management policies can assume a contemporary inclusive reading of human rights that includes migrants independently from the satisfaction of the formal requirement set out by the state.

In this exclusionary strategy, human rights are grounded in physicality thus establishing territorial presence in the destination state or coming under the jurisdiction control of the state agents (Paz, 2017). Moreover, proximity does not entail any legal obligation for the state because jurisdiction is aligned with territory (Paz, 2016). In fact, the legal protection depends on the establishment of a direct presence inside a state (Paz, 2017). The main outcome for such an understanding of human rights is that states externalize interdiction thereby avoiding any direct fingerprint that would activate 
jurisdiction and human rights obligations (Zaiotti, 2016; Frelick et al., 2016; Gabrielli, 2016; Moreno-Lax \& Lemberg-Petersen, 2019).

In the application of inclusive border management policies, a specific elaboration of the concept of human rights materialises. First, human rights are considered as inherent to the individual independently from the individual compliance with formal conditions set by migration management policies (Thomas, 2013). In doing so, human rights protection is initiated by the simple encounter between the state agents and migrants (Mann, 2016). Second, by following such a reading of human rights, state agents consider human rights as universal independently from the physical presence inside the territory of the destination country (Paz, 2016). Therefore, in the application of inclusive strategies, human rights jurisdiction is grounded in proximity to the border without any formal restriction of access to the territory.

To conclude, it seems that the theoretical concepts that composed what has been known as international migration management are often based on simplistic dichotomies. On the one hand, we see a statist, excluding and closed category of human rights. On the other hand, we see a universalist, inclusive and open category of human rights. Yet the core argument here is that human rights as framed so far are able to dominate and exclude migrants. Indeed, the positive power of human rights here is recognized. However, in a world dominated by affluent states the positive discourse around human rights is strong and visible. In light of this, it is important to shed light on the negative impact of human rights: domination and exclusion of human beings based on ideological grounds.

\section{The Mare Nostrum Policies}

The Italian government initiated the Mare Nostrum policies with the aim of: first, saving lives in the Central Southern Mediterranean Sea; and second, fighting against illegal smugglers. The policies lasted from 18 October 2013 to 31 December 2014, during which a number of vessels, helicopters, aeroplanes, drones and personnel of the Italian Navy, Army, Air Force, Carabinieri, Guardia di Finanza, Coast Guard and Police incessantly patrolled the international waters of the Strait of Sicily, looking for migrants at rest, within the Mare Nostrum framework. ${ }^{9}$ The mission was launched directly after

9 For a brief description of the policies see: http://www.marina.difesa.it/cosa-facciamo/operazioniconcluse/Pagine/mare-nostrum.aspx [last visited: 6 May 2019] 
the Lampedusa tragedy of 3 October 2013, when 366 people drowned only half a mile before reaching the island (Cuttitta, 2018a). After this tragedy, the Italian government thought to design a specific policy to manage the space of the sea in the Central Southern Mediterranean. To do so, Mare Nostrum was set up as a kind of humanitarian/military policy (Tazzioli, 2016). By this time, the policies were supported by the principal Italian political parties and by the public opinion that contributed to present the policy as an act of human grace towards migrants departing from North Africa (Tazzioli, 2016; Musarò, 2017; Cuttitta, 2018a).

During the implementation of Mare Nostrum, the Italian government often anticipated its compliance with human rights obligations in time and space in order to save migrants at sea by allowing access to its territory (Cuttitta, 2018a). From a legal perspective, these policies have been designed on the cases decided by human rights Courts and quasi-judicial bodies. In fact, in the case of Mare Nostrum, Italy followed a universal/inclusive framework that considers human rights as integral to the individual independently of the compliance with formal conditions set by migration management policies (Thomas, 2013; Paz, 2016). In doing so, the Italian government has followed a kind of universalist approach to migration management going beyond the formal obligations set up by international law.

Yet while saving lives - thus having a specific humanitarian character - the policies intensified the fight against human being smugglers by increasing the military policies in the Central Southern Mediterranean Sea. In fact, the policies as underlined by several scholars had a dual nature. On the one hand, they represented an act of grace of the Italian government that constructed a strong humanitarian rhetoric. On the other hand, they increased the military interventions during the search and rescue operations in order to identify the smugglers at times present on the boats (Tazzioli, 2016; Musarò, 2017; Cuttitta, 2018a). However, here the paper does not want to stress the dual nature of the Mare Nostrum policies as done by others (Tazzioli, 2016; Musarò, 2017; Cuttitta, 2018a).

The aim instead is to discuss how the assemblage of the concepts of borders, territory, and human rights was instrumental to the political aims demonstrated in Mare Nostrum. Borders are recognized as articulators of human mobility that can assume different elaborations depending on the political objective pursued (Bigo, 2002). In the Mare Nostrum policies, borders are regarded as point of access to the protection of human rights (Paz, 2017). In fact, for migrants to activate protection, it is sufficient for them to 
be in proximity of the border, and thus jurisdiction is associated with physicality and grounded in proximity (Paz, 2016). These types of border elaboration can be recognized in what Walters calls humanitarian border meaning a specific type of border that emerges in a specific setting such as the Mare Nostrum search and rescue operations (Walters, 2011).

While designing an inclusive migration management policy such as Mare Nostrum, the Italian government conceptualized territory in relation to access, jurisdiction, and proximity in the following ways. First, human rights protection was not based on the access to territory of migrants but on their simple proximity to the territory. In doing so, Italy brought to its conclusion the concept developed by the ECtHR in Jamaa vs. Italy that suggests that human rights jurisdiction is 'essentially territorial' ${ }^{10}$ and is aligned with physicality and proximity (Paz, 2016). Second, human rights protection applied extraterritorially, meaning independently from migrants' access to Italy's territory. Therefore, Italy assumed an extended view of human rights that if brought to the extreme can become an open borders policy that identifies no territorial limitation to human right protection (Paz, 2016).

The Mare Nostrum policies were based on a specific elaboration of the concept of human rights. First, in the search and rescue operations human rights are considered as inherent to the individual independently of the individual compliance with formal conditions set by migration management policies (Thomas, 2016; Paz, 2016). In doing so, the Italian government followed a universalist reading of human rights without any formal restriction for migrants to enjoy protection. Second, in following a universal reading of human rights Italy anticipated the compliance with formal requirements by defending human rights independently of the physical presence inside the Italian territory (Paz, 2016).

The Mare Nostrum policies ended in late 2014 and were replaced by the Frontex operation Triton that continued to rescue and disembark migrants in Italy. The operation was supported by $15 \mathrm{EU}$ member states that provided technical equipment and border guards. Yet, the monthly budget allocated to Triton (2.9 million Euros) is less than a third of the budget of Mare Nostrum (Cuttitta, 2014). Furthermore, the Frontex operation had no humanitarian character but was designed as a mission supporting the Italian authorities

${ }^{10}$ Jamaa v. Italy, 2012-II Eur. Ct. H.R. 97, I 71. 
in patrolling the border and collecting intelligence information (Ibid). Moreover, the Triton operation was supported by the Common Security and Defence Policy operation EUNAVFOR Med 'Sophia'. The two operations that replaced Mare Nostrum represented a shift from humanitarianism to securitarianism, and therefore also from inclusion to differential inclusion. This shift is shown by the number of people rescued under the two operations which were less than 7000 in contrast to the 160000 of Mare Nostrum. ${ }^{11}$

In such a scenario the Central Southern Mediterranean was emerging as a place of differential inclusion. There was in fact a gap in the rescue activities of the two new operations. Luckily, this gap was filled by several NGOs ready to rescue migrants at sea and to disembark them in the ports indicated by the Italian Maritime Rescue Coordination Centre. In so doing, NGOs to a certain extent replaced state responsibility (Cusumano \& Pattinson, 2018) and designed an alternative assemblage of borders, territory and human rights. By contrast, with time such activities of NGOs were identified by the Italian public opinion as a pull factor for migrants and smugglers. In other words, NGOs operating in Libyan waters represented a pull factor for smugglers that will organize journeys conscious about the presence of NGOs in the Central Southern Mediterranean Sea ready to rescue migrants. It shall be noted that this pull factor was never confirmed (Villa, 2018). However, it represented one of the casus belli for the shift in migration management policies initiated by former Minister of Interior Marco Minniti.

\section{The Minniti Policies}

The Minniti policies are a specific series of migration management policies initiated by the Italian centre-left government, designed in particular by the former Minister of Interior Marco Minniti (Gargiulo, 2018; Cusumano, 2019). The policies were a response to the significant pressure of right-wing political parties and public opinion following the increase of migrants' arrivals on the Italian shores in $2016 .{ }^{12}$ To respond to this pressure, the Italian government decided to pursue the strategy of externalizing to the

\footnotetext{
${ }^{11}$ For a more information see: https://www.ednh.news/it/da-mare-nostrum-a-triton-il-profilo-dellemissioni-di-salvataggio-tra-italia-e-ue/ [last visited: 28 July 2019]

12 According to the figures presented by the Italian minister of Interior migrants' arrivals in 2016 were 181.436 , almost $18 \%$ of the previous year. While after the signature of the memorandum, migrants' arrivals decreased more than $33 \%$ according to the Italian minister of Interior. For more information see: https://www.ilsole24ore.com/art/notizie/2017-01-05/migranti-2016-record-sbarchi-eaccoglienza162035.shtml?uuid=ADdVMwQC; http://www.interno.gov.it/it/notizie/meno-33-sbarchi-nel2017 [last visited: 27 April 2019]
} 
Libyan Coast Guard the search and rescue operations in the Central Southern Mediterranean Sea (de Guttry et al., 2017; Moreno-Lax \& Lemberg-Petersen, 2019). This externalization policy was formalized by the signature of a memorandum of understanding between Libya and Italy (2017). The memorandum prefigured among others: the provision of equipment and training for the Libyan Coast Guard; an important financial support; and the establishment of detention centres in Libya managed exclusively by the Libyan Minister of Interior (de Guttry et al., 2017; Reviglio, 2019). Moreover, Minniti adopted a Code of Conduct regulating the rescue of migrants by NGOs and in doing so paved the way for the criminalization of NGOs because they were accused of representing a pull factor and a promoter of human smuggling across the Central Southern Mediterranean (Cusumano, 2019).

This type of migration management policy is part of a wider European strategy that goes in the direction 'remote control' (Guirudon \& Lahav, 2000) or 'control from distance' (Bialasiewicz, 2012). To secure this type of management strategy, countries adopt bilateral or multilateral soft law agreements in order to externalize the management activities putting in place instruments to construct a securitized border through 'securitizing practices' (Campesi, 2014, 2018; Gabrielli, 2016). As in the case of the memorandum between Libya and Italy, the design of a securitized border displays two characteristics: first, it makes easier the containment of migration flows; second, it enables an externalization of search and rescue activities to third countries as in the Libyan case. Thus, according to the exclusionary policy, the border only permits the entry of those individuals who comply with the formal conditions set out by the state. However, in some cases countries put in place instruments to make it more difficult for migrants to reach the border as in the case of the memorandum where the search and rescue activities are externalized to the Libyan Coast Guard in order for Italy to avoid any direct international responsibilities (Moreno-Lax, 2018; Reviglio, 2019).

The Minniti policies brought to the extreme can become a closed borders policy because they put in place a series of instruments aimed at blocking the arrivals and at externalizing the search and rescue activities to third countries. While pursuing such a policy, Italy had first to recognize human rights jurisdiction as associated to access to territory because migrants have to enter state territory or to come under the jurisdiction of the state agents (Paz, 2017). It emerges from this approach that jurisdiction is rooted in strong territoriality, meaning that human rights obligations are strictly territorial (Paz, 
2016). Second, for Italy, state jurisdiction and thus state responsibilities will manifest themselves only if there is a direct access to the territory of the destination state.

In the design of this externalizing migration policies, Italy represents the sole authority able to give access to its territory and to set the legal conditions to access human rights protection in doing so it follows the statist reading (Thomas, 2016). Further, by recognizing human rights grounded in territory, proximity does not entail any legal obligation for Italy because jurisdiction is aligned with territory (Paz, 2016). In doing so, the legal protection depends on the establishment of a direct presence inside a state (Paz, 2017). Therefore, Italy externalizes or outsources interdiction thereby avoiding any direct fingerprint that would trigger jurisdiction and human rights obligations. In doing so, affluent states like Italy reinforce their exclusive practices by adopting externalizing migration policies (Zaiotti, 2016; Frelick et al., 2016; Gabrielli, 2016; Moreno-Lax \& Lemberg-Petersen, 2019).

Yet it shall be noted that the policies pursued by Minniti, despite externalizing the border and criminalizing NGOs (Cusumano, 2019), did not completely relinquish responsibility for rescue operations. A last phase characterized by outright exclusion was initiated in June 2018 by the right-wing new Minister of Interior Matteo Salvini. This new phase of outright exclusionary policies became the cornerstone of Italy's migration management policies. In such an exercise, a new assemblage of borders, territory and human rights characterized by outright exclusion emerged. Indeed, the exclusionary policies were initiated by Minniti nonetheless Salvini implemented some substantial measures that created a situation of outright exclusion. In particular, Salvini initiated a policy of 'closed ports' that as Cusumano and Gombeer (2018) point out is not illegal per se but has severe consequences from a humanitarian point of view. By doing so, NGOs' activities were subject to many measures that intentionally created the conditions for illegality for rescue and disembarkation operations in Italy conducted by NGOs. ${ }^{13}$

An even more exclusionary assemblage materializes through Salvini's policies. Borders are regarded as an obstacle to access and thus to the protection of human rights. Moreover, it is not enough to come under the direct control of the Italian Coast Guard to

${ }^{13}$ See: Decree Law N. 113 of 4 October 2018, https://www.gazzettaufficiale.it/eli/id/2018/10/04/18G00140/sg; Decree Law N. 53 of 14 June 2019, https://www.gazzettaufficiale.it/eli/id/2019/06/14/19G00063/sg [last visited: 27 July 2019] 
activate human rights protection as the Diciotti case shows. ${ }^{14}$ Thus, as exemplified by the Diciotti case, in Salvini's policies for migrants is not sufficient to enter the territory and to come under direct control of the state to enjoy human rights protection (Paz, 2017). In Salvini's policies, jurisdiction is not territorial, yet it seems to be enacted only upon direct decision of the Minister of Interior through an executive order without any respect for the concept of territory and of international law. Indeed, as noted by Cusumano and Gombeer (2018), the humanitarian consequences of such policies are significant. In fact, in Salvini's outright exclusionary policies is not sufficient for migrants to establish direct presence inside the state to activate human rights protection.

Thus, the assemblage designed by Salvini is emerging as a cornerstone of Italy's migration management policies. In this setting, exclusion is brought further with significant humanitarian consequences for migrants crossing the Central Southern Mediterranean Sea. Yet Salvini's policies of outright exclusion continue to unfold and do need further studies to identify their exclusionary power and humanitarian consequences. In particular, it is crucial to assess the legal validity of such measures in relation to international law, the law of the sea and human rights law.

\section{Conclusion}

The EU and its member states overlooking the Mediterranean Sea in the last decades have developed a system of migration management that is based on the decisions of European courts and quasi-judicial bodies. The compromise developed by the courts has reinforced the inclusion vs. exclusion dichotomy that is nowadays displayed in some recent migration management policies designed by Italy. This trend in migration management policies is part of a European approach to migration management that goes in the direction of 'remote control' and 'control from distance' in order to externalize to third states the search and rescue activities and the detention of migrants.

In this scenario, the paper has analyzed the migration management policies designed by Italy and Europe between 2013 and 2019. In particular, it has focused on two policies developed to overcome the so called 'migration crisis': The Mare Nostrum

\footnotetext{
${ }^{14}$ See for a detailed account of the case: http://opiniojuris.org/2018/08/28/the-kafkaesque-diciotti-case-initaly-does-keeping-177-people-on-a-boat-amount-to-an-arbitrary-deprivation-of-liberty/ [last visited: 27 July 2019]
} 
policies and the Minniti policies. The main argument of the paper is that these policies are based on the instrumental assemblage of three components: borders, territory, and human rights. In fact, these migration management assemblages emerge as a policy to either include or exclude migrants from the destination country. Indeed, the narratives of the two competing migration management discourses represent two completely different perspectives on migration. On the one hand, the Mare Nostrum policies were presented as a humanitarian/securitarian mission that had as priority saving lives at sea. On the other hand, the Minniti policies emerged aimed at limiting the arrivals of migrants by externalizing to the Libyan forces the search and rescue policies and the detention of migrants in Libya. To do so, these policies followed by the Italian government assembled borders, territory and human rights in order to justify their 'momentaneous' political objectives: open borders/inclusion vs. closed borders/exclusion.

In the Mare Nostrum policies, human rights protection was not based on the access to territory of migrants but on their simple proximity and physicality to the territory. Second, human rights protection applied extraterritorially and thus Italy assumed an extended view of human rights that identifies no territorial limitation to human rights protection. While in the Minniti policies, human rights protection was based on the migrants' access to the border and their presence in the territory in order to activate protection. In fact, migrants have to enter the territory and come under direct control of the state. Hence, human rights protection depends on the establishment of a direct presence inside a state. In so doing, Italy externalizes or outsources interdiction thereby avoiding any direct fingerprint that would activate jurisdiction and human rights obligations.

To sum up, the paper has discussed these two migration management policies to show that in designing these policies states build upon the compromise between inclusion and exclusion developed by European courts. Moreover, in the elaboration of these policies, states assemble instrumentally borders, territory and human rights to justify their political objectives. Thus, it is important to shed light on these assemblages in order to identify new horizons for migration management strategies because the so called 'migration crisis' will continue to unfold in the next decades. In this light, further studies are needed to scrutinize the contemporary migration management policies enacted by Salvini that go into the direction of outright exclusion. Nonetheless, the direction taken 
by the EU and its member states seems to be more in favor of exclusion and closed borders for migrants. In light of these developments, it seems that the Mare Nostrum policies represented an isolated and perhaps unrepeatable inclusionary and humanitarian/securitarian migration management policies. 


\section{Bibliographical References}

Aalberts, T. E. \& Gammeltoft-Hansen, T. (2014) 'Sovereignty at Sea: The law and Politics of Saving Lives in Mare Liberum' Journal of International Relations and Development, 17(4); 439-68.

Adepoju, A., Van Noorloos, F. \& Zoomers, A. (2010) 'Europe's Migration Agreements with Migrant-Sending Countries in the Global South: A Critical Review' International Migration, 48(3); 42-75.

Agnew, J. (1994) 'The Territorial Trap: The Geographical Assumptions of International Relations Theory' Review of International Political Economy, 1(1); 53-80.

Agnew, J. (2008) 'Borders on the Mind: Re-Framing Border Thinking' Ethics \& Global Politics, 1(4); 175-91.

Agnew, J. A., Mitchell, K. \& Toal, G. (eds.) (2008) A Companion to Political Geography. Oxford: Blackwell.

Algostino, A. (2017) 'L'esternalizzazione Soft Delle Frontiere e il Naufragio della Costituzione' Costituzionalismo.it, (1); 139-82.

Badie, B. (1996) 'La Fin des Territoires Westphaliens' Géographie et Cultures, 20; 11318.

Balibar, É. (2012) Politics and the Other Scene. London: Verso.

Banai, A., Moore, M., Miller, D., Nine, C. \& Dietrich, F. (2014) 'Symposium Theories of Territory Beyond Westphalia’ International Theory, 6(1); 98-104.

Baxi, U. (2007) The Future of Human Rights. Oxford: Oxford University Press.

Bialasiewicz, L. (2012) 'Off-shoring and Out-Sourcing the Borders of Europe: Libya and EU Border Work in the Mediterranean’ Geopolitics, 17(4); 843-66.

Bigo, D. (2002) 'Security and Immigration: Toward a Critique of the Governmentality of Unease' Alternatives, 27; 63-92.

Brenner, N. \& Elden, S. (2009) 'Henri Lefebvre on State, Space, Territory' International Political Sociology, 3(4); 353-77.

Brighenti, A. M. (2010) 'Lines, Barred Lines. Movement, Territory and the Law' International Journal of Law in Context, 6(3); 217-27.

Campesi, G. (2014) 'Frontex, the Euro-Mediterranean Border and the Paradoxes of Humanitarian Rhetoric' Southeast European Journal of Political Science, 2(3); 126-34.

Campesi, G. (2018) 'Crisis, Migration and the Consolidation of the EU Border Control Regime' International Journal of Migration and Border Studies, 4(3); 196-221.

Casas, M., Cobarrubias, S. \& Pickles, J. (2010) 'Stretching Borders Beyond Sovereign Territories? Mapping EU and Spain's Border Externalization Policies' Geopolitica (s), 2(1); 71-90.

Cusumano, E. (2019) 'Straightjacketing Migrant Rescuers? The Code of Conduct on Maritime NGOs’ Mediterranean Politics, 24(1); 106-14. 
Cusumano, E. \& Gombeer, K. (2018) 'In Deep Waters: The Legal, Humanitarian and Political Implications of Closing Italian Ports to Migrant Rescuers' Mediterranean Politics; 1-9.

Cusumano, E. \& Pattison, J. (2018) 'The Non-Governmental Provision of Search and Rescue in the Mediterranean and the Abdication of State Responsibility' Cambridge Review of International Affairs, 31(1); 53-75.

Cuttitta, P. (2007) Segnali di Confine. Il Controllo dell'immigrazione nel Mondofrontiera. Mimesis.

Cuttitta, P. (2014) 'From the Cap Anamur to Mare Nostrum. Humanitarianism and migration controls at the EU's maritime borders' in C. Matera and A. Taylor (eds.), The Common European Asylum System and Human Rights: Enhancing Protection in Times of Emergencies, The Hague: Asser Institute; pp. 21-37.

Cuttitta, P. (2018a) 'Delocalization, Humanitarianism, and Human Rights: The Mediterranean Border between Exclusion and Inclusion' Antipode, 50(3); 783803.

Cuttitta, P. (2018b) 'Inclusion and Exclusion in the Fragmented Space of the Sea. Actors, Territories and Legal Regimes between Libya and Italy' in E. Burroughs and K. Williams (eds.), Contemporary Boat Migration: Data, Geopolitics and Discourses, London: Rowman \& Littlefield; pp. 75-94.

De Genova, N. (2013) 'Spectacles of Migrant 'Illegality': The Scene of Exclusion, the Obscene of Inclusion’ Ethnic and Racial Studies, 36(7); 1180-98.

De Genova, N., Mezzadra, S. \& Pickles, J. (2015) 'New Keywords: Migration and Borders' Cultural Studies, 29(1); 55-87.

de Guttry, A., Capone, F. \& Sommario, E. (2018) 'Dealing with Migrants in the Central Mediterranean Route: A Legal Analysis of Recent Bilateral Agreements Between Italy and Libya' International Migration, 56(3); 44-60.

de Sousa Santos, B. (2002) 'The Processes of Globalisation' Reč, (68/14); 67-131.

Elden, S. (2013) The Birth of Territory. Chicago: University of Chicago Press.

Frelick, B., Kysel, I. M. \& Podkul, J. (2016) 'The Impact of Externalization of Migration Controls on the Rights of Asylum Seekers and other Migrants' Journal on Migration and Human Security, (4)4; 190-220.

Gabrielli, L. (2016) 'Multilevel Inter-Regional Governance of Mobility Between Africa and Europe: Towards a Deeper and Broader Externalisation' GRITIM Working Paper Series Number 30 - Winter 2016.

Gargiulo, E. (2018) 'Una Filosofia della Sicurezza e dell'ordine. Il Governo dell'immigrazione Secondo Marco Minniti' Meridiana, (91); 151-73.

Geiger, M. \& Pécoud, A. (2010) 'The Politics of International Migration Management' in M. Geiger and A. Pécoud (eds.), The Politics of International Migration Management. Migration, Minorities and Citizenship, London: Palgrave Macmillan; pp. 1-20.

Guiraudon, V. \& Lahav, G. (2000) 'A Reappraisal of the State Sovereignty Debate: The Case of Migration Control' Comparative PoliticalSstudies, 33(2); 163-95. 
Falk, R. (2008) Achieving Human Rights. Ney York: Routledge.

Foucault, M. (2007) 'Questions on Geography' in D. M. Wood, J. W Crampton and S. Elden (eds.), Space, Knowledge and Power: Foucault and Geography, Farnham: Ashgate Publishing; pp. 173-82.

Hampshire, J. (2016) 'European Migration Governance since the Lisbon Treaty: Introduction to the Special Issue' Journal of Ethnic and Migration Studies, 42(4); 537-53.

Hardt, M. \& Negri, A. (2001) Empire. Cambridge: Harvard University Press.

Jeandesboz, J. \& Pallister-Wilkins, P. (2016) 'Crisis, Routine, Consolidation: The Politics of the Mediterranean Migration Crisis’ Mediterranean Politics, 21(2); 316-20.

Johnson, C., Jones, R., Paasi, A., Amoore, L., Mountz, A., Salter, M. \& Rumford, C. (2011) 'Interventions on Rethinking 'The Border' in Border Studies' Political Geography, 30(2); 61-9.

Kennedy, D. (2002) 'International Human Rights Movement: Part of the Problem?’ Harvard Human Rights Journal, 15; 101.

Knight, D. B. (1982) 'Identity and Territory: Geographical Perspectives on Nationalism and Regionalism' Annals of the Association of American Geographers, 72(4); 514-31.

León, A. I. \& Overbeek, H. (2015) 'Neoliberal Globalization, Transnational Migration and Global Governance' in L. S. Talani and S. McMahon (eds.), Handbook of the International Political Economy of Migration, Cheltenham: Edward Elgar Publishing; pp. 37-53.

Lorca, A. B. (2017) 'Human Rights in International Law? The Forgotten Origins of Human Rights in Latin America' University of Toronto Law Journal, 67(4); 46595.

Macklem, P. (2015) The Sovereignty of Human Rights. Oxford: Oxford University Press.

Mann, I. (2016) Humanity at Sea: Maritime Migration and the Foundations of International Law. Cambridge: Cambridge University Press.

Mann, I. (2017) 'Human Rights as Thought Experiments' Journal of International Law and International Relations, 13; 20.

Marks, S. (2013) 'Four Human Rights Myths' in D. Kinley, W. Sadurski and K. Walton (eds.), Human Rights: Old Problems, New Possibilities, Cheltenham: Edward Elgar Publishing; pp. 217-35.

Mezzadra, S. \& Neilson, B. (2013) Border as Method, or, the Multiplication of Labor. Durham: Duke University Press.

Moore, M. (2015) A Political Theory of Territory. Oxford: Oxford University Press.

Moreno-Lax, V. (2012) 'Hirsi Jamaa and Others v Italy or the Strasbourg Court versus Extraterritorial Migration Control?' Human Rights Law Review, 12(3); 574-98. 
Moreno-Lax, V. (2018) 'The EU Humanitarian Border and the Securitization of Human Rights: The 'Rescue-Through-Interdiction/Rescue-Without-Protection 'Paradigm' Journal of Common Market Studies, 56(1); 119-40.

Moreno-Lax, V. \& Lemberg-Petersen, M. (2019) 'Border-induced Displacement: The Ethical and Legal Implications of Distance-Creation through Externalization' Questions of International Law, 56(1); 5-33.

Moyn, S. (2012) The last Utopia. Cambridge: Harvard University Press.

Moyn, S. (2014) 'A Powerless Companion: Human Rights in the Age of Neoliberalism' Law and Contemporary Problems, 77; 147-69.

Musarò, P. (2017) 'Mare Nostrum: The Visual Politics of a Military-Humanitarian Policies in the Mediterranean Sea' Media, Culture \& Society, 39(1); 11-28.

Novak, P. (2017) 'Back to Borders’ Critical Sociology, 43(6); 847-64.

O'Connell, P. (2007) 'On Reconciling Irreconcilables: Neo-Liberal Globalisation and Human Rights' Human Rights Law Review, 7(3); 483-509.

Paasi, A. (2003) 'Territory' in J. A. Agnew, K. Mitchell and G. Toal (eds.), A Companion to Political Geography, Hoboken: John Wiley \& Sons; pp. 109-22.

Pallister-Wilkins, P. (2017) 'Humanitarian Borderwork' in C. Günay and N. Witjes (eds.), Border Politics: Defining Spaces of Governance and Forms of Transgressions, Cham: Springer; pp. 85-103.

Paz, M. (2016) 'Between the Kingdom and the Desert Sun: Human Rights, Immigration, and Border Walls' Berkeley Journal of International Law, 34; 1-43.

Paz, M. (2017) 'The Law of Walls' European Journal of International Law, 28(2); 60124.

Raz, J. (2010) 'Human Rights in the Emerging World Order' Transnational Legal Theory, 1(1); 31-47.

Reviglio, M. (2019) 'Externalizing Migration Management through Soft Law: The Case of the Memorandum of Understanding between Libya and Italy' Global Jurist (forthcoming).

Sack, R. D. (1986) Human Territoriality: its Theory and History. Cambridge: Cambridge University Press.

Sassen, S. (2008) Territory, Authority, Rights: From Medieval to Global Assemblages. Princeton: Princeton University Press.

Sassen, S. (2013) 'When Territory Deborders Territoriality' Territory, Politics, Governance, 1(1); 21-45.

Sohn, C. (2014) 'Modelling Cross-Border Integration: The Role of Borders as a Resource' Geopolitics, 19(3); 587-608.

Spijkerboer, T. (2018) 'The Global Mobility Infrastructure: Reconceptualising the Externalisation of Migration Control' European Journal of Migration and Law, 20(4); 452-69. 
Steinhilper, E. \& Gruijters, R. J. (2018) 'A Contested Crisis: Policy Narratives and Empirical Evidence on Border Deaths in the Mediterranean' Sociology, 52(3); 515-33.

Tazzioli, M. (2016) 'Border Displacements. Challenging the Politics of Rescue biBetween Mare Nostrum and Triton' Migration Studies, 4(1); 1-19.

Terpan, F. (2015) 'Soft Law in the European Union: The Changing Nature of EU Law' The European Law Journal, 21(1); 68-96.

Thomas, C. (2013) 'What Does the Emerging International Law of Migration Mean for Sovereignty?' Melbourne Journal of International Law, 14; 1-59.

Villa, M. (2018). 'Sbarchi in Italia: il Costo delle Politiche di Deterrenza' Commentary ISPI. Available: https://www.ispionline.it/it/pubblicazione/sbarchi-italia-il-costodelle-politiche-di-deterrenza-21326 [last visited: 22 ${ }^{\text {nd }}$ July 2019]

Zaiotti, R. (ed.) (2016) Externalizing Migration Management: Europe, North America and the Spread of 'remote Management' Practices. New York: Routledge.

Zanini, P. (1997) Significati del Confine: i Limiti Naturali, Storici, Mentali. Milano: Pearson Italia Spa.

Zapata-Barrero, R. \& Gabrielli, L. (2017) 'Ethics and the Securitization of Migration: Reversing the Current Policy Framework', in P. Bourbeau (ed.), Handbook on Migration and Security, Cheltenham. Edward Elgar Publishing; pp. 125-43. 